\title{
New species of Holopedium Zaddach, 1855 (Crustacea: Cladocera: Ctenopoda) from Greenland
}

\author{
Nikolai M. KOROVCHINSKY
}

A.N. Severtsov Institute of Ecology and Evolution of the Russian Academy of Sciences, Leninsky Prospect 33, 119071 Moscow, Russia

e-mail: nmkor@mail.ru

\begin{abstract}
The genus Holopedium remains poorly studied. Its nominal species $\mathrm{H}$. gibberum was superficially described; later morphological differences of representatives of this taxon, especially in North America, have been recorded but not investigated in detail. The Greenlandic members of the taxon, listed for the first time in 1889, have never been precisely studied. Meanwhile, their comparative analysis resulted in the description of a new species, $\mathrm{H}$. groenlandicum, which differs from $\mathrm{H}$. gibberum s. l. in having a dorsally low shell and jelly envelope, shorter row of valve marginal spinules which are subdivided in groups, and comparatively longer postabdominal claws. Morphologically, the new species seems more primitive than $\mathrm{H}$. gibberum. Absence of males and the presence of resting eggs may indicate a pseudosexual or another, poorly understood, mode of reproduction. Holopedium groenlandicum inhabits only permanent water bodies, mostly along the south-western and western coast of Greenland up to $71^{\circ} \mathrm{N}$. This species is endemic to the island, and is most probably of relict nature.
\end{abstract}

Key words: Cladocera, Holopedium, new species, Greenland

\section{INTRODUCTION}

The genus Holopedium, represented by a single species, $H$. gibberum Zaddach, 1855, was described for the first time in the middle of the $19^{\text {th }}$ century from the vicinity of Königsberg (now Kaliningrad City, Russia) (Zaddach 1855). This and some subsequent descriptions (Sars 1865; Beck 1883; Lilljeborg 1901) seemed detailed enough due to the uniqueness of these crustaceans. Nevertheless, they missed a number of features which I suggest are important in the taxonomy of the genus. Later descriptions of $H$. gibberum, which became known as having a holarctic distribution (Ueno 1937; Šramek-Husek et al. 1962; Manuilova 1964; Brooks 1959; Flössner 1972, 2000; Margaritora 1985; Korovchinsky 1992, 2004), were even less detailed and often borrowed data from Lilljeborg's monograph.

In North America, pronounced morphological differences have been detected in some Holopedium populations, members of which were sometimes presumed to be related to different species (Tessier 1986; Montvilo et al. 1987; Korovchinsky 1992; Hebert \& Finston 1997). Rowe (2000) stated the plurality of the genus in North America and described, in particular, two new species close to $H$. gibberum. He focused mainly on genetic characteristics of taxa, while morphological features were poorly studied. All his results, however, remain unpublished. Thus, by the 150year anniversary of its description, the only well known holarctic taxon, $H$. gibberum s.l., which obviously represents a species group, remains inadequately studied from the modern point of view.
In Greenland, representatives of the genus (Holopedium gibberum) were recorded originally by Guerne \& Richard (1889) in their first large list of Cladocera of the island. Later on, this taxon was listed in almost every publication on Greenlandic freshwater fauna (Stephensen 1913; Haberbosch 1916, 1920; Linder 1932) but no researcher attempted to describe the local holopediums in any details except Røen (1962) who presented a photo of a general view of an adult female.

In October - November 2003 I had an opportunity to study the cladoceran collection deposited in the Zoological Museum of Copenhagen University (Denmark), in particular, numerous samples with Holopedium from Greenland (most of them were collected by Dr. U. Røen) and some European localities. Close comparative examination of the Greenlandic representatives of the taxon revealed noticeable morphological differences both from those occurring in Eurasia (putatively identified as $H$. gibberum s.l.) and North America. As a result, I concluded they belong to a new species of the genus which is described below.

Abbreviations: ZMUC - collection of the Zoological Museum of Copenhagen University; NMK - personal author's collection.

\section{MATERIAL AND METHODS}

\subsection{Material from Greenland (ZMUC)}

West Greenland: 1) Oplhsnil, 14.07.1890, 1 female; 2) Karajak-Fjord, 07.07.1906, 1 female; 3) Sartarsqil, 03.08.1906, 1 female. 
Tab. 1. Proportions of body parts of Holopedium groenlandicum sp. nov. from two populations (in each column from top to down: limits of variation, mean, CD, CV). Abbreviations: BL - body length, HL - head length, LDS and LPS length of distal and proximal antennal branch segments, SH - shell height, LP - length of postabdomen, LSN length of setae natatoriae, LPC - length of postabdominal claws.

\begin{tabular}{|c|c|c|c|c|c|}
\hline $\begin{array}{c}\text { HL:BL } \\
(\%)\end{array}$ & $\begin{array}{c}\text { LDS:LPS } \\
(\%)\end{array}$ & $\begin{array}{c}\text { SH:BL } \\
(\%)\end{array}$ & $\begin{array}{c}\text { LP:BL } \\
(\%)\end{array}$ & $\begin{array}{c}\text { LSN:BL } \\
(\%)\end{array}$ & $\begin{array}{c}\text { LPC:LP } \\
(\%)\end{array}$ \\
\hline \multicolumn{6}{|c|}{ Godthåbfjord, sample 706: $64^{\circ} 23^{\prime} \mathrm{N} ; 5^{\circ} 19^{\prime} \mathrm{W}, 21.07 .1973, \mathrm{n}=15$} \\
\hline $21.1-26.7$ & $75.0-95.5$ & $76.8-100.0$ & $21.1-27.6$ & $8.7-10.8$ & $33.3-40.0$ \\
\hline 24.2 & 85.5 & 88.8 & 24.4 & 9.7 & 36.7 \\
\hline 1.6 & 5.6 & 6.4 & 1.8 & 0.6 & 2.1 \\
\hline 6.6 & 6.6 & 7.2 & 7.4 & 6.5 & 5.7 \\
\hline \multicolumn{6}{|c|}{ Godthåbfjord, sample $778: 64^{\circ} 27^{\prime} \mathrm{N} ; 5^{\circ} 33^{\prime} \mathrm{W}, 15.08 .1973, \mathrm{n}=15$} \\
\hline $21.1-29.7$ & $70.6-93.3$ & $64.1-86.5$ & $21.5-27.8$ & $8.3-11.1$ & $34.8-43.5$ \\
\hline 23.8 & 81.9 & 74.0 & 24.0 & 9.8 & 40.1 \\
\hline 2.6 & 6.2 & 5.3 & 1.6 & 0.8 & 2.8 \\
\hline 11.0 & 7.5 & 7.2 & 6.7 & 7.7 & 6.9 \\
\hline
\end{tabular}

Disko Fjord: 4) Loh 25, 29.07.1957, some females; 5) Loh 57, Chrisharshås, 18.06.1957, some juv. females; 6) Loh 79, Giescho Sø, 30.08.1957, some females; 7) Loh 81, Vandirsøen Egedesmde, 9.07.1957, some juv. females; 8) Loh 87, Orpigsôq, 23.8.1957, 1 female.

Kap Farvel: 9) sample 527, Spongilla Sø, 5958’ N; $44^{\circ} 21^{\prime} \mathrm{W}, 19.07 .1970$, numerous females; 10) 535, $59^{\circ} 38^{\prime} \mathrm{N} ; 4^{\circ} 21^{\prime} \mathrm{W}, 18.07 .1970,1$ juv. female; 11) 570, $60^{\circ} 03^{\prime} \mathrm{N} ; 44^{\circ} 17^{\prime} \mathrm{W}, 29.07 .1970$, some juv.

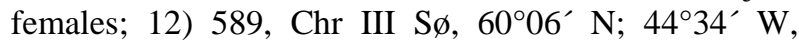

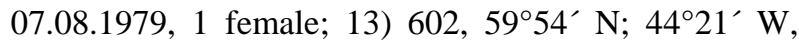
12.08.1970, 1 female.

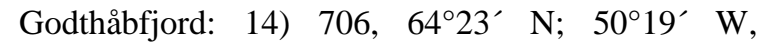
21.07.1973, numerous females; 15) $715,64^{\circ} 24^{\prime} \mathrm{N}$; $50^{\circ} 11^{\prime} \mathrm{W}$, 28.07.1973, numerous females; 16) 730,

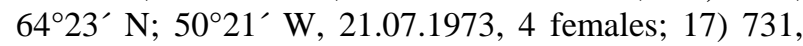
$64^{\circ} 22^{\prime} \mathrm{N}$; 502' W, 21.07.1973, 1 female; 18) 746, $64^{\circ} 25^{\prime} \mathrm{N} ; 50^{\circ} 12^{\prime} \mathrm{W}, 05.08 .1973$, numerous females; 19) $747,64^{\circ} 23^{\prime} \mathrm{N} ; 50^{\circ} 13^{\prime} \mathrm{W}, 05.08 .1973$, some females; 20) $765,64^{\circ} 27^{\prime} \mathrm{N}$; $50^{\circ} 17^{\prime} \mathrm{W}, 09.08 .1973$, some females; 21) $772,64^{\circ} 23^{\prime} \mathrm{N}$; $50^{\circ} 17^{\prime} \mathrm{W}$, 11.08.1973, 2 females; 22) $774,64^{\circ} 27^{\prime} \mathrm{N}$; $51^{\circ} 33^{\prime} \mathrm{W}$, 15.08.1973, 4 females; 23) $777,64^{\circ} 28^{\prime} \mathrm{N}$; 51 $51^{\circ} 33^{\prime} \mathrm{W}$, 15.08.1973, numerous females; 24) $778,64^{\circ} 27^{\prime} \mathrm{N}$; 51.033 $\mathrm{W}, 15.08 .1973$, numerous females; 25) 782, $64^{\circ} 28^{\prime} \mathrm{N}$; $51^{\circ} 33^{\prime} \mathrm{W}, 15.08 .1973$, some females; 26) 789, $64^{\circ} 28^{\prime} \mathrm{N}$; $50^{\circ} 13^{\prime} \mathrm{W}, 17.08 .1973$, 1 female; 27) $804,64^{\circ} 27^{\prime} \mathrm{N} ; 5^{\circ} 32^{\prime} \mathrm{W}, 19.08 .1973$, numerous females; 28) $811,64^{\circ} 27^{\prime} \mathrm{N}$; 51 ${ }^{\circ} 33^{\prime} \mathrm{W}, 19.08 .1973$, numerous females; 29) $820,64^{\circ} 28^{\prime} \mathrm{N}$; $51^{\circ} 33^{\prime} \mathrm{W}$, 21.08.1973, 1 female; 30) $829,64^{\circ} 27^{\prime} \mathrm{N}$; $51^{\circ} 36^{\prime} \mathrm{W}$,

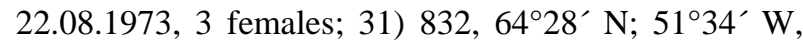
26.08.1973, numerous females.

\subsection{Other materials}

ZMUC. Samples: 1) Denmark, "CRU - 3922, 3923, 3924, 3926, Bügholm Sö, Hellebock, 20.07.1869, coll. L. Lund, Holopedium gibberum", numerous females; 2) Denmark, CRU - 3920, 3921, Madum Sø, 13.06.1942, H. gibberum", some females; 3) Sweden, "Upland,
Holopedium gibberum, Lilljeborg determ.", some females.

Total mounts: 1) Denmark: "P.E. Müller, Holopedium gibberum Zadd., Bügholm Sóe, 7 - 65", 4 females; 2) Denmark, "Klare Só, Hellebock, 24.06.1924, Holopedium gibberum", 6 mounts with 6 females; 3) Sweden, "Jämtland, Frostuikens sn. L. Väkte sjön, 8-8. 99, Holopedium gibberum", 2 females; 4) Sweden, "Jämtland, Åre sn. Myrgl paa Malsen. T. Borch leg., 13.6.33, Holopedium gibberum", 4 females; 5) Germany, "Titisee, 17.10.07, Holopedium gibberum", 1 dissected female.

NMK. Samples: 1) Russia, Unnamed lake in Lapland Reserve, Kola Peninsula, summer 1972, numerous females, leg. A.M. Ghilarov; 2) Russia, Lake Kurgalovskoe in the nearest vicinity of St.-Petersburg, 16.06.1977, numerous females, leg. A.V. Makrushin.

\subsection{Measurements, drawings and SEM micrographs}

Fifteen females from two Greenlandic populations (samples 706 and 778) and the two Russian populations mentioned above were taken for detailed measurements. These measurements were made according to Korovchinsky (2004). Tests of significant differences were accomplished using the Wilcoxon coefficient.

Drawings were made by means of a Zeiss compound microscope with a camera lucida.

Scanning electron microscopy was performed on specimens and eggs after dehydration in alcohol of increasing concentrations, acetone, and subsequent critical point drying. Mandibles were prepared without dehydration; their description is according to Edwards' (1980) terminology. After sputter-coating with gold, the preparations were examined with a JEOL JSM $6335 \mathrm{~F}$ microscope at the Zoological Museum of Copenhagen University.

\section{RESULTS}

\subsection{Holopedium groenlandicum sp. nov.}

Proportions of body parts are shown in Table 1. 


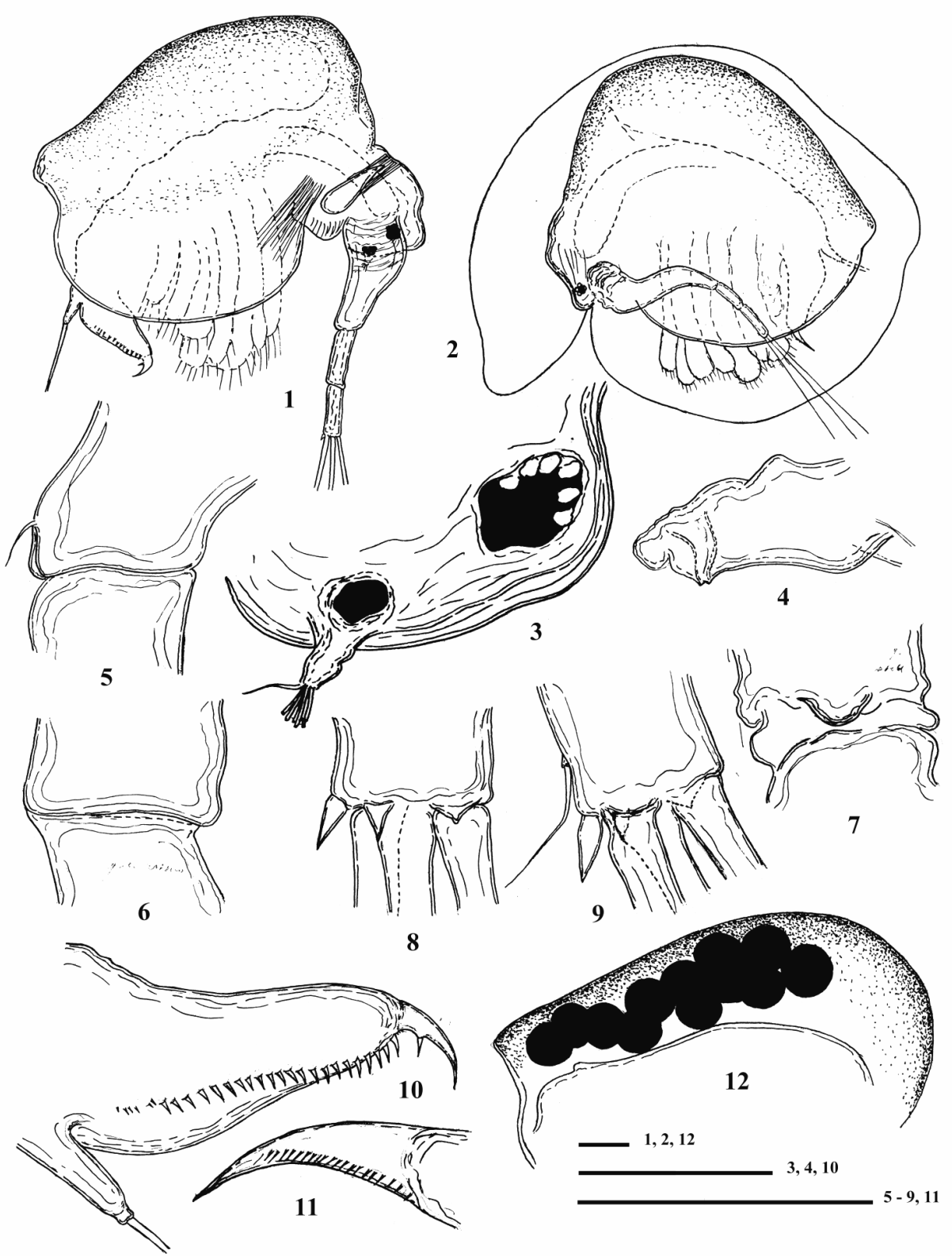

Plate 1. Figs 1 - 12. Holopedium groenlandicum sp. nov., females. Greenland, Godthåbfjord, sample 706, 21.07.1973.

1. General lateral view; 2. Female in jelly envelope; 3. Antero-ventral part of head; 4. Labrum; 5. Distal end of antennal basipodite, outer side; 6. Union of two segments of antennal branch; 7. Distal end of antennal basipodite, inner side; 8. Distal end of antennal branch, inner side; 9. The same, outer side; 10. Postabdomen, lateral view; 11. Abnormal postabdomenal claw without basal spine; 12. Eggs in brood pouch. Scale bars $=200 \mu \mathrm{m}$.

\subsubsection{Etymology}

Species is named after the island whose water bodies it inhabits.

\subsubsection{Description}

Female. Body massive with head $(21.1-29.7 \%$ of body length) bent almost at right angle to thorax (Pl. 1, Fig. 1). Jelly envelope with comparatively massive frontal part and weakly developed dorsal one (Pl.1, Fig. 2).
Frontal head margin with embayment, its anteriorventral corner roundish (Pl. 1, Figs 1, 3). Eye small, ocellus comparatively large, situated near base of antennules which are small with six aesthetascs and a short sensory seta on the apical end (Pl. 1, Fig. 3).

Swimming antennae long with long and massive basipodite having a small seta on postero-distal corner and roundish outgrowth in inner apical position (Pl. 1, Figs 5, 7). Single two-segmented antennal branch, distal segment is narrower and shorter (70.6-95.5\% of length of proximal one) with three long swimming setae, small 
subapical seta, two denticles, and one triangular outgrowth on its apical end (Pl. 1, Figs 6, 8, 9; Pl. 3, Fig. 1).

Labrum massive with a gland opening on its ventral side (Pl. 1, Fig. 4).

Mandibles asymmetric, the general shape of their molar plates triangular with a broadened posterior part (Pl. 3, Figs 2, 3). Posterior edge of right mandible (Pl. 3, Fig. 2) bears $4-5$ sharpened pegs, diminishing in size ventrally. Along its entire dorsal edge 17-18 elongated pales: 3-4 posterior ones sharpened, others with more or less roughly brushed tips. Along the ventral margin 1112 anteriorly curved fishbones, anteriormost of which are widened. Central part of molar plate slightly concave. Posteriorly it bears rounded outgrowths diminishing in size ventrally. Anteriorly outgrowths small, smoothed, forming parallel rows (diagonals) going across the surface from bases of fishbones to pales.

Left mandible (Pl. 3, Fig. 3) with a group of six massive, blunt projections on the dorsal angle of posterior broad side. Along dorsal and posterior margins rows of elongated rod-like outgrowths with densely brushed tips: one such row along dorsal margin and several rows near posterior margin. Similar row of outgrowths with roughly brushed tips along ventral margin. Central part of molar surface smooth.

Shell comparatively low (64.1-100.0\% of body length) and with dorsal margin sloping back moderately, creating roundish or roundish-rectangular prominence posteriorly (Pl. 1, Figs 1, 2, 12). Valves rather small, oval, not covering thoracic limbs and postabdomen. Along almost the whole their entire margins they have a long row of small, submarginal spines (Pl. 2, Figs 1, 2; Pl. 3, Figs 4, 5), sometimes subdivided into groups. Anteriormost spines are smaller and sparsely situated, those on antero-ventral margin always create a fan-like group, the rest are usually bent somewhat posteriorly. In smaller specimens from sample 778 the subdivision of these spinules into groups is almost indistinguishable.

Thoracic limbs of ordinary structure, having no differences from that of $H$. gibberum (see Korovchinsky 2004) (Table 2; Pl. 2, Figs 4-11).

Abdomen with a dorso-lateral transverse belt of tiny, densely situated spinules (Pl. 2, Fig. 3).

Postabdomen cone-like and massive (21.1-27.8\% of body length) with lateral rows of 17-24, more often 1821, anal denticles (Pl. 1, Fig. 10; Pl. 4, Fig. 1) which may be sometimes paired. These rows are usually followed proximally by few small spines. In addition, lateral sides of postabdomen are covered by numerous rows and clusters of spinules, those above anal denticles are crest-like (Pl. 4, Figs 1, 2). Base of setae natatoriae long (8.3 - $11.1 \%$ of body length). Postabdominal claws (33.3-43.5\% of postabdomen length) are strongly bent and possess one prominent basal spine (Pl. 1, Fig. 10; Pl. 4, Figs 1, 2) which is rarely absent (Pl. 1, Fig. 11). Distally, claws bear a long, lateral, submarginal row of small spines, dorsal to which their whole surface is covered by densely situated rows and groups of spinules (Pl. 4, Fig. 2).

Body length $0.74-1.98 \mathrm{~mm}$. Many females bore many, up to 27 , eggs of spherical shape $(0.17-0.18 \mathrm{~mm}$ in diameter) in their brood pouches (Pl. 1, Fig. 12; Pl. 3, Fig. 6).

\subsubsection{Morphological variability}

In spite of a pronounced difference in body length (\# 706: 1.44 - $1.82 \mathrm{~mm}$ and \# 778: 1.12 - $1.31 \mathrm{~mm}$ ), the two quantitatively analyzed sets of specimens of the new species demonstrate reasonable similarity in their means and variability (see Table 1 ). Of the parameters under consideration, the relationship of head length/body length in specimens from sample 778 seems to be more variable, but interpopulation comparisons reveal similarity. Also, comparative shell height looks rather different in the two populations, probably due to differences in body dimensions, because larger specimens from sample 706 have relatively higher shells. The number of anal denticles is also increased in larger specimens (\# 706: 18-24 and \# 778: 17-21 respectively).

\subsubsection{Type material}

Holotype - female with body length $1.70 \mathrm{~mm}$ from sample 706 (Greenland, Godthåbfjord, 64²3' N; $50^{\circ} 19^{\prime}$ W, 21.07.1973, coll. U. Røen). Deposited in Crustacean collection of Zoological Museum of Copenhagen University in a tube with alcohol, catalog number CRU - 3933.

Paratypes - all specimens from Greenland used in this investigation and enumerated above.

20 females are deposited in the Zoological Museum of Moscow State University, catalog number $\mathrm{Ml}-55$.

\subsubsection{Differential diagnosis}

The generally well known holarctic taxon $H$. gibberum s.l. is poorly studied morphologically and taxonomically. However, representatives of this taxon from different regions (e.g., Sars 1865, 1993; Lilljeborg 1901; Šramek-Husek et al. 1962; Manuilova 1964; Brooks 1959; Flössner 1972, 2000; Korovchinsky 1992; Røen 1995; Rowe 2000; see also Pl. 5, Figs 1, 2) demonstrate consistent differences from the Greenlandic specimens in the form and size of the shell and jelly envelope. They usually have a high, dome-shaped shell and a jelly envelope well-developed dorsally, whereas $H$. groenlandicum possesses a comparatively low shell with a moderately sloping dorsal margin and a jelly envelope that is poorly developed dorsally.

More detailed observations of a few European populations of $H$. gibberum (the present study and unpublished author's data) revealed other differences that distinguish them from this new species. 


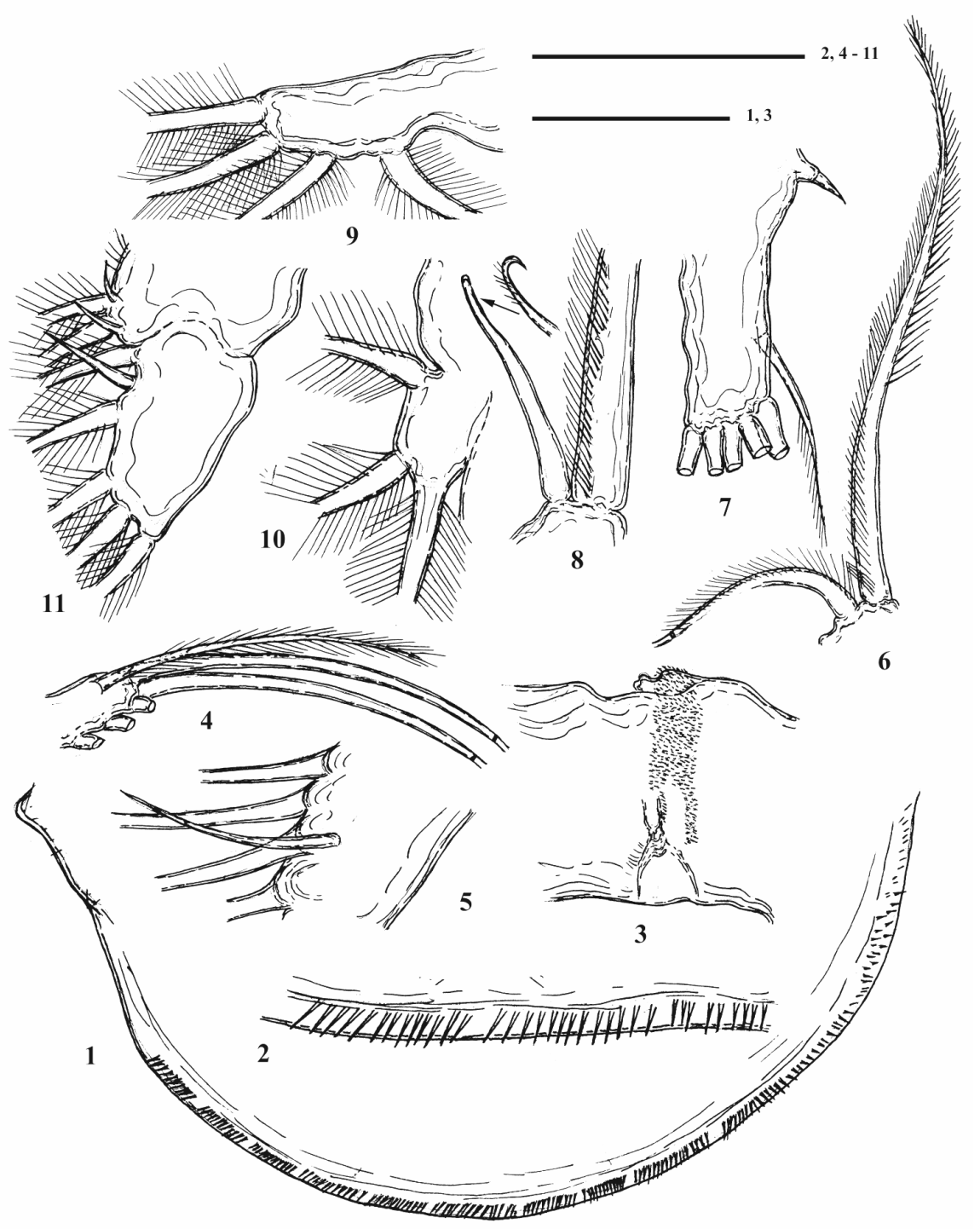

Plate 2. Figs 1 - 11. Holopedium groenlandicum sp. nov., females. Greenland, Godthåbfjord, sample 706, 21.07.1973.

1. Armament of shell margin; 2. Spinules of shell margin; 3. Belt of tiny abdominal spinules; 4 . End of endopodite of thoracic limb I; 5. Small seta above the row of endopodital filtering setae of thoracic limb I; 6. Large non-filtering setae on distal gnathobasic corner of thoracic limb I; 7. End of exopodite of thoracic limb II, inner side; 8. Hooked spine on distal corner of gnatobase of thoracic limb II; 9. Exopodite of thoracic limb V; 10. Exopodite of thoracic limb VI; 11. Endopodite of thoracic limb VI. Scale bars $=200 \mu \mathrm{m}$.

Tab. 2. Structure and armament of thoracic limbs of Holopedium groenlandicum sp. nov. ( $\mathrm{n}$ - number of endopodital and gnatobasic filtering setae, 1 , 2, etc. - number of apical and lateral soft exopodital and endopodital setae, I and i - modified setae of distal gnatobasic corner and lateral exopodital spines).

\begin{tabular}{ccccc}
\hline Limb & Exopodite & Endopodite & Gnatobase & Epipodite \\
\hline I & $5+5$ & $\mathrm{n} 39+1$ & $\mathrm{n} 21+\mathrm{I}+\mathrm{i}$ & - \\
II & $6+\mathrm{i}$ & $\mathrm{n} 42+1$ & $\mathrm{n} 24+\mathrm{I}+\mathrm{i}$ & + \\
III & $6+\mathrm{i}$ & $\mathrm{n} 39+1$ & $\mathrm{n} 25+\mathrm{I}+\mathrm{i}$ & + \\
IV & 5 & $\mathrm{n} 30+1$ & $\mathrm{n} 23+\mathrm{I}+\mathrm{i}$ & + \\
V & 4 & $\mathrm{n} 22+1$ & $\mathrm{n} 23+\mathrm{I}+\mathrm{i}$ & - \\
VI & 3 & $5+1$ spine & $2+2$ spines & - \\
\hline
\end{tabular}



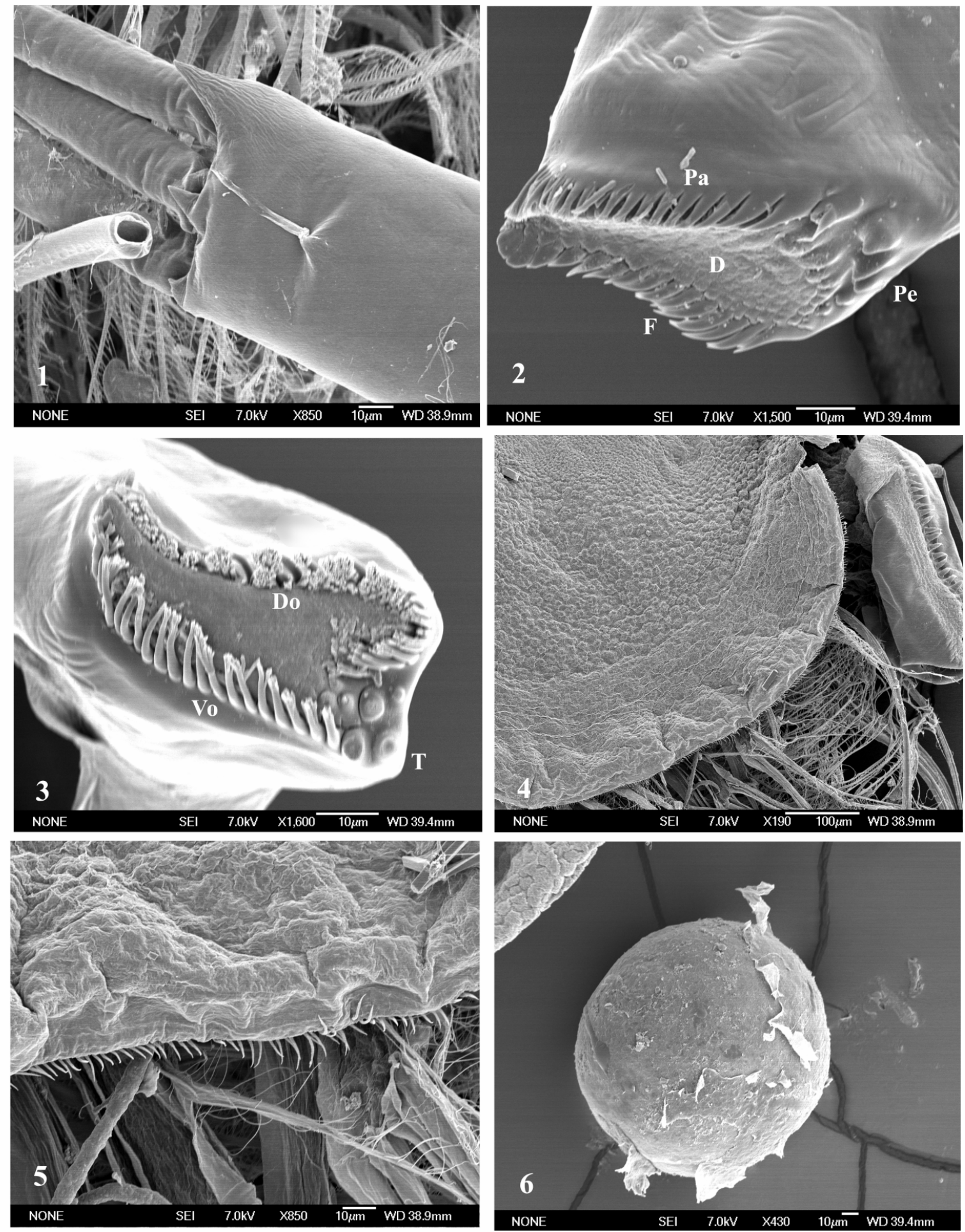

Plate 3. Figs 1 - 6. Holopedium groenlandicum sp. nov., females. Greenland, Godthåbfjord, sample 706, 21.07.1973.

1. End of antennal branch; 2. Right mandible ( $\mathrm{Pe}$ - pegs, $\mathrm{Pa}$ - pales, $\mathrm{F}$ - fishbones, $\mathrm{D}$ - diagonals); 3. Left mandible ( $\mathrm{T}$ - blunt teeth, Do - dorsal outgrowths, Vo - ventral outgrowths); 4. Postero-ventral part of shell valve; $\mathbf{5}$. Spinules of valve margin; $\mathbf{6}$. Egg. 

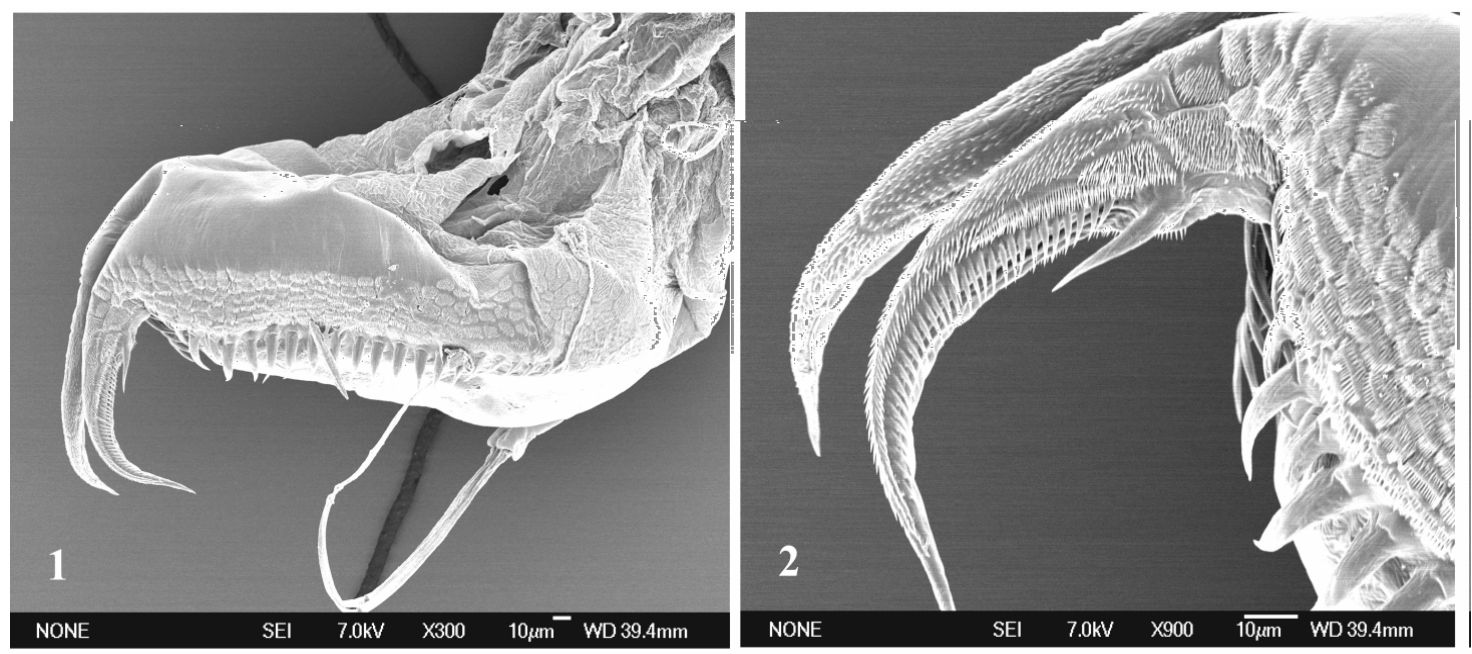

Plate 4. Figs 1, 2. Holopedium groenlandicum sp. nov., females. Greenland, Godthåbfjord, sample 706, 21.07.1973.

1. Postabdomen, lateral view; 2. Distal part of postabdomen and claws.

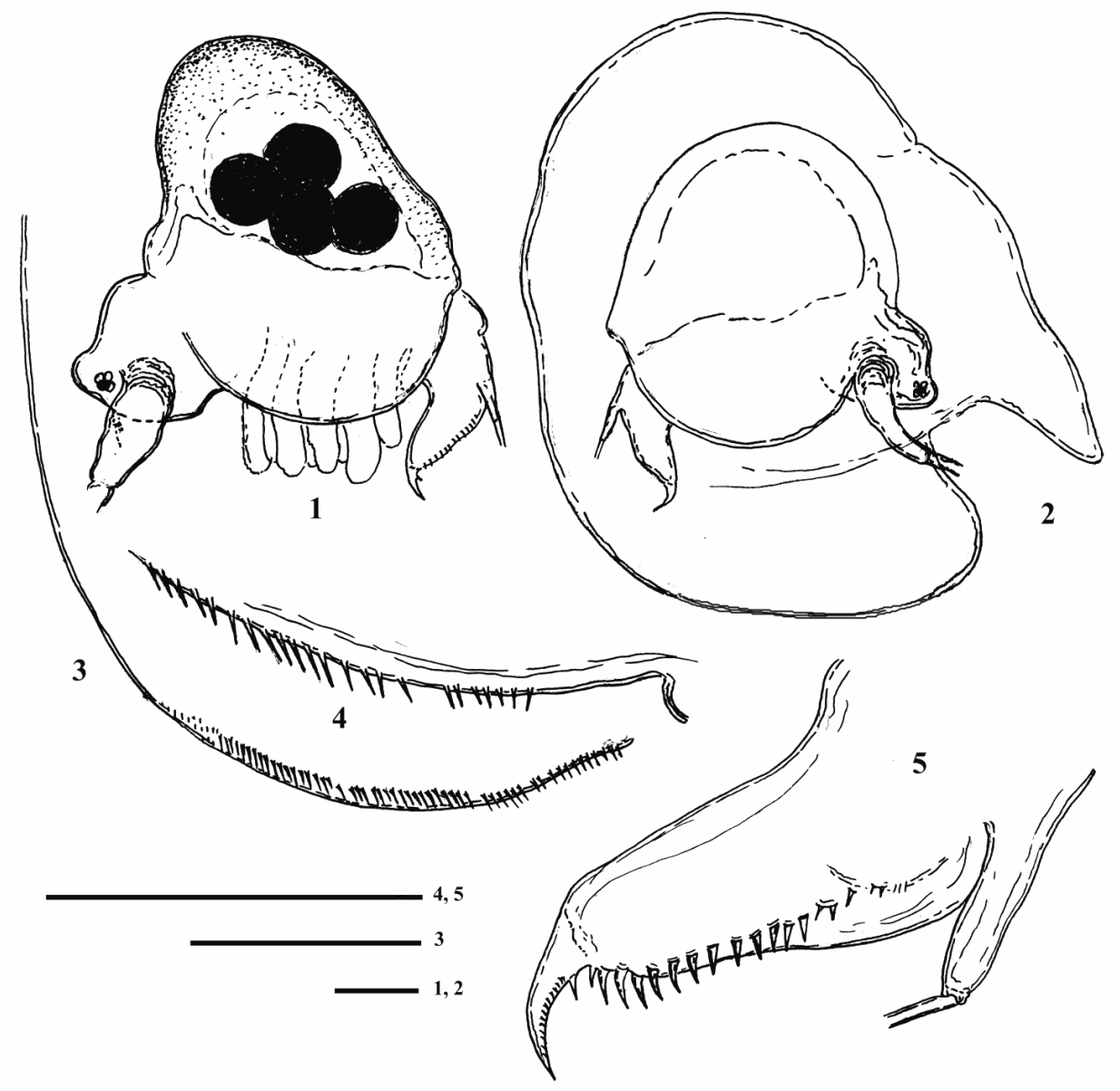

Plate 5. Figs 1 - 5. Holopedium gibberum Zaddach, 1855, females. Bughölm Sö, Hellebock, Denmark, 20.07.1869, coll. L. Lund. 1. General lateral view; 2. Female in jelly envelope; 3. Armament of shell margin; 4. Spinules of shell margin; 5. Postabdomen, lateral view. Scale bars $=200 \mu \mathrm{m}$. 


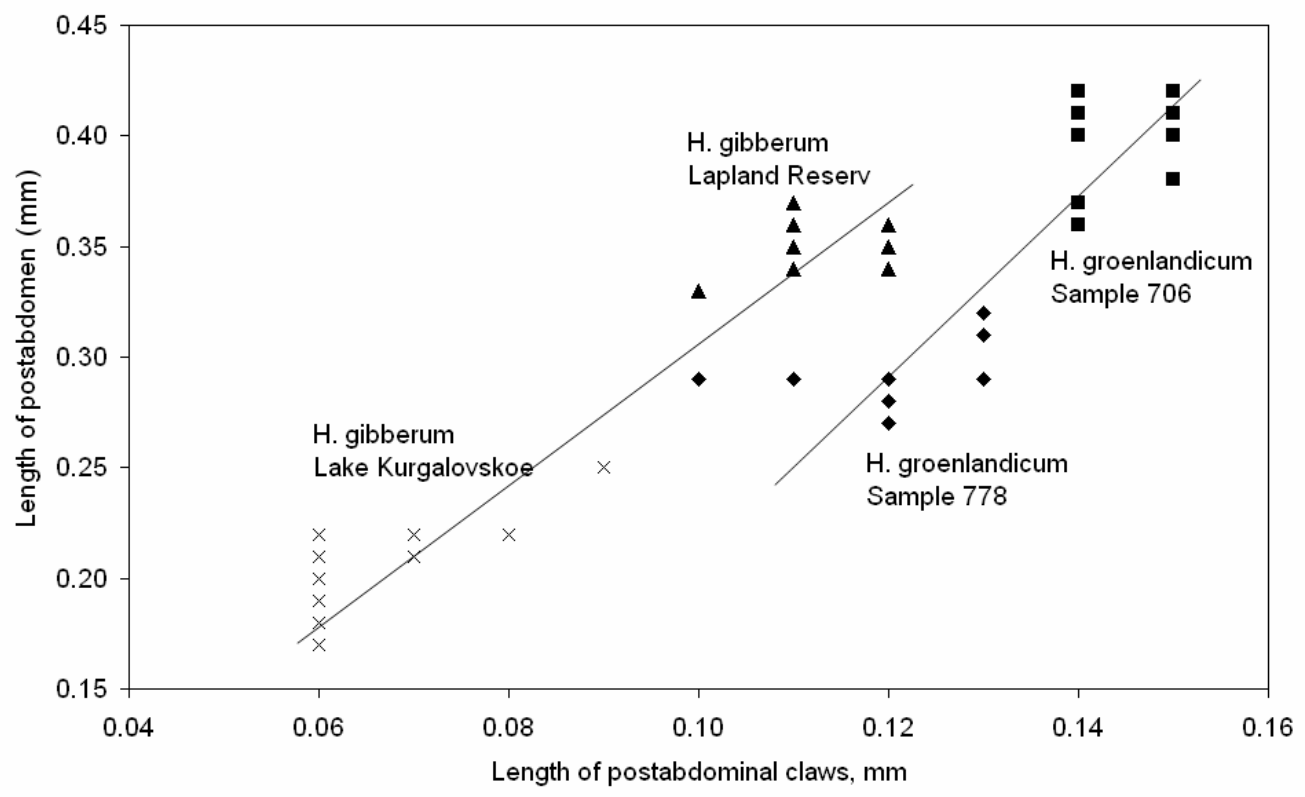

Fig. 1. Relationships of length of postabdominal claws and length of postabdomen in $H$. gibberum and $H$. groenlandicum from two populations each.

In $H$. gibberum the submarginal row of spinules on the shell margin occupies only half or slightly more of the posterior shell margin and is not subdivided into groups, whereas in $H$. groenlandicum it occupies most of the margin and, especially in larger specimens, is subdivided into groups. The postabdominal claws of the new species are significantly longer, in relation to postabdomen length (33.3 - 43.5\%), than in $H$. gibberum (28.2 - 35.6\%) from the Russian localities listed above $(p<0.001 ; \mathrm{n}=30)$ (Fig. 1). Lastly, the anal denticles of $H$. groenlandicum were usually found to be more numerous than in most individuals of $H$. gibberum (cf. Pl. 5, Fig. 5), but this apparent difference needs further investigation.

\section{DISCUSSION}

The inability to provide an adequate taxonomic analysis of the taxon $H$. gibberum was probably based in large degree on psychological grounds. Any quite peculiar and routinely easily-identifiable form is readily accepted as an undifferentiated unit. Similar examples were shown, for instance, by the taxa Chydorus sphaericus (O.F. Müller 1785), Chydorus faviformis Birge, 1893, and Diaphanosoma mongolianum Ueno, 1938 which, after revision, turned out to be species groups (Frey 1980, 1987; Korovchinsky 1987). This was only possible through detailed morphological investigation and comparison of their representatives from different, often distantly isolated, populations.

For a long time, only a few researchers noted morphological variability within the taxon $H$. gibberum (Sars 1890; Stingelin 1904; Scheffelt 1908) and the existence of intermediate forms between this species and H. amazonicum Singelin, 1904 (Carpenter 1931; Bunting 1970; Korovchinsky 1992). Some distinguishable features, both morphological (body size, number of anal denticles, shape of jelly envelope) and genetic, have been observed in North American forms (Tessier 1986; Montvilo et al. 1987; Hebert \& Finston 1997; Rowe 2000) but there has been little effort to provide their detailed morphological analysis.

Røen (1962) mentioned that all Greenlandic holopediums possess a specific feature - a comparatively small shell height, but he did not propose their taxonomic separation, and only suggested this trait was environmentally induced morphological variability. The only extant image made by this author (1962, p.140, Fig. 27) shows a typical $H$. groenlandicum with a low shell and low jelly envelope.

The present study confirmed the taxonomic importance of such features as the form and size of the jelly envelope, and revealed several other important diagnostic features including: form of the shell, armament of the valve margin, and size of the postabdominal claws relative to the postabdominal length.

At the same time, no differences in the structure of thoracic limbs and mandibles were found. Strictly speaking, the left mandible of the new species has a small specificity - smaller and blunter posterior teeth compared with those of $H$. gibberum (see Glagolev \& Korovchinsky 1992) but the general occurrence of this feature remains unclear.

Compared to $H$. gibberum, the morphology of $H$. groenlandicum seems more primitive because individuals of this species have a less dorsally developed shell (the shape being closer to that of other cladocerans), less 
well-developed jelly envelope, and more numerous spinules along the valve margins.

The life cycle of zooplanktonic organisms in northern latitudes is short (Ekman 1905; Vekhov 1982). According to Haberbosch (1916), gamogenetic reproduction in Greenlandic Holopedium starts in July. Indeed, many females of $H$. groenlandicum bore dark resting eggs with a solid shell in their brood pouches. No researcher who has studied Greenlandic holopediums has recorded males in their populations, and none were found in this study. This may imply the existence of a pseudosexual mode of reproduction in $H$. groenlandicum. Such a mode is known in a few species of Arctic Daphnia. In their populations, however, males are often present just to transmit genes suppressing meiosis (Hebert 1987; Colbourne et al. 1997). On the other hand, this may be a mode of reproduction that is unique for the Cladocera, such as automictic parthenogenesis, that was proposed for Canadian Arctic H. gibberum by Rowe (2000).

Holopedium groenlandicum is not very common in Greenlandic freshwaters, occurring at most in $20 \%$ of water bodies of any particular area (see Røen 1962, 1997). It inhabits upper layers of permanent water bodies: large and small lakes, and ponds (Haberbosch 1920; Røen 1962, 1994), infrequently dominating zooplankton communities (Røen 1997).

Holopedium groenlandicum is mostly distributed along the south-western and western coast of Greenland up to $71^{\circ} \mathrm{N}$. In the east of this island it is known only in two localities in the Scoresby Sund area (Røen 1962). This species is especially common in Diskofjord and Godthåbfjord areas while in the southernmost Kap Farvel area it is found only in five localities of its western part (Røen 1962, 1994, 1997).

The described new species is an endemic to Greenland, and is most probably of relict nature, judging from its comparatively primitive morphological features and very limited range. The numerical prevalence of the species in particular areas (Diskofjord, etc.) known to be glacial refugia (Weider et al. 1996), suggests its probable survival in such habitats from much earlier times.

\section{ACKNOWLEDGMENTS}

I am much indebted to Dr. J. Olesen who kindly organized my visit to the Zoological Museum of Copenhagen University for his hospitality and various help and Mr. B. Beisbolle for his assistance with SEM. Dr. M. Petersen and Dr. L. Hausmann also graciously helped me during my work in the Zoological Museum. Prof. A.M. Ghilarov (Moscow State University, Moscow, Russia) and Dr. A.V. Makrushin (Institute of Biology of Inland Waters, Borok, Russia) kindly supplied me with samples with Holopedium from Kola Peninsula and the S. Petersburg area. Prof. N.N. Smirnov (Institute of Ecology and Evolution, Moscow,
Russia) made linguistic revision of the text. Valuable comments and corrections by Prof. D. Berner (Temple University, Philadelphia, USA) and two anonymous referees provided further improving of the manuscript. This study was supported by the Russian Foundation for Basic Research (grant 03 - 04 - 48879).

\section{REFERENCES}

Beck, C. 1883. On some new Cladocera of the English lakes. J. Roy. Microsc. Soc. (ser. 2), 3: 777-784.

Brooks, J.L. 1959. Cladocera. In: W.T. Edmonson, (Ed.), Freshwater biology. $2^{\text {nd }}$ Edition. J. Wiley \& Sons, New York: 587-656.

Bunting, D.L. 1970. The Cladocera and Copepoda of Tennessee: 1 . Limnetic Cladocera of east Tennessee and the TVA reservoirs. J. Tenn. Acad. Sci., 45: 2-5.

Carpenter, K.E. 1931. Variations in Holopedium species. Science, 74: 550-551.

Colbourne, J., P.D.N. Hebert \& D.T. Taylor. 1997. Evolutionary origin of phenotypic diversity in Daphnia. In: T.J. Givnish \& K.J. Sytsma (Eds), Molecular evolution and adaptive radiation. Cambridge Univ. Press: 163-188.

Edwards, C. 1980. The anatomy of Daphnia mandibles. Trans. Am. Microsc. Soc., 99: 2-24.

Ekman, S. 1904. Die Phyllopoden, Cladoceren und freilebende Copepoden der nord - schweidischen Hochgebirge. Ein Beitrage zur Tiergeographie, Biologie und Systematic der arktischen, nord- und mittel-europäien Arten. Zool. Jahrb. Abt. Syst., 21(1): 1-170.

Flössner, D. 1972. Kiemen- und Blattfüsser, Branchiopoda, Fishläuse, Branchiura. Tierwelt Deutschlands. 60. G. Fischer Verlag, Jena: 501 pp.

Flössner, D. 2000. Die Haplopoda und Cladocera (ohne Bosminidae) Mitteleuropas. Backhuys Publishers, Leyden: $428 \mathrm{pp}$.

Frey, D.G. 1980. On the plurality of Chydorus sphaericus (O.F. Müller) (Cladocera, Chydoridae) and designation of a neotype from Sjaelsø, Denmark. Hydrobiologia, 69: 83123.

Frey, D.G., 1987. The North American Chydorus faviformis (Cladocera, Chydoridae) and the honeycombed taxa of other continents. Phil. Trans. Roy. Soc. London, B315: 353-402.

Glagolev, S.M. \& N.M. Korovchinsky. 1992. The structure of molar surfaces of the mandibles of Sidoidea. 1. Holopedium gibberum. Int. Revue ges. Hydrobiol., 77: 325-329.

Guerne de, J \& J. Richard. 1889. Sur la faune des eaux douces du Groenland. C. R. Acad. Sci. Paris, 108: 88-93.

Haberbosch, P. 1916. Über arktische Süsswassercrustaceen. Zool. Anz., 47: 134-144.

Haberbosch, P. 1920. Die Süsswasserentomostracen Grönlands. Z. Hydrol., 1: 136-184, 245-249.

Hebert, P. D.N. 1987. Genotypic characteristics of the Cladocera. Hydrobiologia, 145: 183-193.

Hebert, P.D.N. \& T.L. Finston. 1997. Taxon diversity in the genus Holopedium (Crustacea: Cladocera) from the lakes of eastern North America. Can. J. Zool., 54: 1928-1936.

Korovchinsky, N.M. 1987. A study of Diaphanosoma species (Crustacea: Cladocera) of the "mongolianum" group. Int. Revue ges. Hydrobiol., 72: 727-758.

Korovchinsky, N.M. 1992. Sididae \& Holopediidae. Guides to the identification of the microinvertebrates of the continental waters of the world, 3. SPB Acad. Publishers, The Hague: 82 pp.

Korovchinsky, N.M. 2004. Cladocera of the order Ctenopoda (morphology, systematics, ecology, zoogeography). KMK, Moscow: 410 pp. (in Russian). 
Lilljeborg, W. 1901. Cladocera Sueciae oder Beitrage sur Kenntnis der in Schweden lebenden Krebstiere von der Ordnung der Branchiopoden und der Unterordnung der Cladoceren. Nova Acta reg. soc. sci. upsal. (ser. 3), 19: 1-701.

Linder, F. 1932. Die Branchiopoden des arktischen Gebietes. Fauna Arctica, 6: 185-204.

Manuilova, E.F. 1964. Cladocera of the USSR. Identification manuals on the USSR fauna, 88. Nauka, Moscow Leningrad: 372 pp. (in Russian).

Margaritora, F. 1985. Cladocera. Fauna d'Italia, 23. Bologna: 399 pp.

Montvilo, J.A., M.A. Hegyi \& M.J. Kevin. 1987. Aspects of the anatomy of the jelly coat of Holopedium and certain other cladocerans. Trans. Am. Microsc. Soc., 106: 105-113.

Røen, U. 1962. Studies on freshwater Entomostraca in Greenland. II. Localities, ecology, and geographical distribution of the species. Medd. Grønland, 170: 1-249.

Røen, U. 1994. Studies on freshwater Entomostraca in Greenland. VI. The Entomostraca of the Kap Farvel Area, southernmost Greenland. Medd. Grønl. Bioscience, 41: 3-21.

Røen, U. 1995. Gaellefødder (Branchiopoda). Ferejer, Damrokker, Muslingeskalkrebs \& Daphnier samt Karpelus (Branchiura). Denmarks Fauna, 85. København: 358 pp.

Røen, U. 1997. The Cladocera of the Godthåbfjord area, SW Greenland. Hydrobiologia, 360: 75-78.

Rowe, C.L. 2000. Global distribution, phylogeny and taxonomy of the freshwater zooplankton genus Holopedium. Thesis MSc. University of Guelph, Ontario, Canada: 323 pp.

Sars, G.O. 1865. Norges Ferskvandskrebsdyr Forste afsnit Branchiopoda. I. Cladocera Ctenopoda (Sididae \& Holopedidae). Efter det Academiske Collegium, Christiania: $71 \mathrm{p}$.

Received: April 2005

Accepted: August 2005
Sars, G.O. 1890. Oversigt af Norges crustaceer med foreløbige Bemaerkninger over de nye eller mindre bekjendte Arter. II. Branchiopoda - Ostracoda - Cirripedia). Forhandl. Vidensk.- Selskab. Christiania: 1 - 80.

Sars, G. O. 1993. On the freshwater crustaceans occurring in the vicinity of Christiania. University of Bergen: $197 \mathrm{pp}$.

Scheffelt, E. 1908. Die Copepoden und Cladoceren des südlichen Schwarzwaldes. Arch. Hydrobiol., 4: 37-79.

Šramek-Husek, R., M. Straškraba \& J. Brtek. 1962. Lupenonozci - Branchiopoda. Fauna ČSR, 16: 470 pp.

Stephensen, K. 1913. Grønlands Krebsdyr og Pycnogonider (Conspectus Crustaceorum et Pycnogonidorum Groenlandiae). Medd. Grønland., 22: 1-479.

Stingelin, T. 1904. Die Familie der Holopedidae. Rev. Suisse Zool., 12: 53-64.

Tessier, A.J. 1986. Life history and body size evolution in Holopedium gibberum Zaddach (Crustacea, Cladocera). Freshwat. Biol., 16: 279-286.

Ueno, M. 1937. Order Branchiopoda (Class Crustacea). Fauna Nipponica: $135 \mathrm{pp}$.

Vekhov, N.V. 1982. The distribution and ecology of some Cladocera in Subarctic water bodies of the European part of the USSR. Vestnik zoologii, 4: 43-48. (in Russian).

Weider, L.J., A. Hobaek, T.J. Crease \& H. Stibor. 1996. Molecular characterization of clonal population structure and biogeography of arctic apomictic Daphnia from Greenland and Iceland. Molec. Ecol., 5: 107-118.

Zaddach, E. G. 1855. Holopedium gibberum, ein neues Crustaceum aus der Familie der Branchiopoden. Arch. Naturgesh., 21(1): 159-188. 